\section{Levels of Health}

PUBLIC health administrators have long been interested in devising heslth indices to measure the state of heslth of a population. At a meeting convened by the United Nations in 1953, on the international definition and standardization of measurement of levels of living, health was considered to be the most important item in a list of twelve constituent factors in standards of living. In the report of a study group acting on behalf of the World Health Organization (Technical Report Series, No. 137: Measurement of Levels of Health. Pp. 29. Geneve: World Health Organization; London: H.M. Stationery Office, 1957. 1s. 9d.) the concept of health and the knowledge available on the subject of the measurement of levels of health is reviewed. So far, the decrease in death-rates and the extension of life expectancy have been taken as indicators of improvements in the standard of health. The study group find that this procedure is not adequate. It has examined statistical data on health and suggests possible new health indicators in the fields of nutrition, environmontal sanitation and mental health. It considers that counting the number of doctors and hospital beds in terms of population-ratio, without going into their effective use by the population, affords no criterion of health. The group finds that present knowledge and experience on this subject are inadequate and recommends that special field studies and research work should be carried out by medical and health institutions in order to devise more satisfactory indices for measuring levels of health, particularly the positive aspects of health.

\section{The Selection and Training of Managers}

A BOоKLEт by Col. L. Urwick answers some of the questions troubling businesses concerned with selecting and training future managers ("Sixteen Questions about the Selection and Training of Managers". By Lyndall F. Urwick. Pp. 36. London : Urwick, Orr and Partners, Ltd., 1958. 2s. 6d.). Whom should a business look for as potential managers, when and how? Having selected them, how should it train them and what facilities exist to help? Are some businesses too small to use these facilities? What will be their worst problem in training managers ? Col. Urwick lists his answers in note form so that the possibilities available to a business under each question can be seen quickly. Ten years ago Col. Urwick was chairman of the government committee which established the "Urwick Syllabus" of management courses now being given in some eighty British technical colleges. The national scheme is at present under some criticism, notably from older business men and from university-educated management trainees, as being too long and too slow for their needs. Col. Urwick restates the limited aims of the national scheme and points out that different training possibilities are open to these two special categories of people.

\section{Organization of Respiration}

IN an investigation of the respiration in chlorophyllous cells, W. O. James and V. S. R. Das (New Phytol., 56, 325 ; 1957) point out that the catalysts of respiration must be spatially separated and organized within plant cells and that they are likely to be distributed among different organelles. In particular, they have inquired if chloroplasts respire, and if they obtain products of respiration from other cell com. ponents. The materials selected for study were the young leaves of the broad bean and spinach beet, the chloroplasts being isolated and purified from accompanying mitochondria. Although highly active in the Hill reaction, these chloroplasts showed no oxygen consumption and were unable to reduce diphosphopyridine nucleotide in the dark. They could not oxidize cytochrome $c$, or any of the Krebs cycle acids, or pyruvate in the presence of malate. Broken chloroplasts showed no greater oxygen consumption than unbroken. Mitochondria from the same leaves rapidly oxidized cytochrome $c$ acids of the Krebs cycle, and pyruvate after addition of malate. Light and electron microscopic observations revealed no special spatial aggregations of chloroplasts and mitochondria; but the paucity of cytoplasm in the cells cauces distances between chloroplasts and mitochondria to be always very short. The authors have suggested that carbon mobilization, glycolysis and oxidation go on in the chloroplasts, 'soluble' cytoplasm and mitochondria, respectively.

\section{Hosts of Schistosoma}

Writ the appearance of "Intermediate Hosts of Schistosoma" by Dr. G. Mandahl-Barth (World Health Organization Monograph No. 37. Pp. $89+40$ plates. London: H.M. Stationery Office, 1958. 12 Swiss francs ; 20s. ; 4 dollars), a notable advance in the field of medical malacology has been made. Here, for the finst time, is a volume in which the African Planorbidae of medical importance are considered together, without regard to political frontiers, by a competent malacologist who has devoted many years to their study. Dr. MandahlBarth would be the last to suggest that his work is the final solution to all of the taxonomic problems in this most difficult group. It does, however, provide a reasonable classification which, if adopted by all field-workers, will serve as a sound basis for future discussion. The author deserves the gratitude of all who work on problems of medical biology in Africa.

\section{Measurement of Air Pollution}

THere are several lines of approach to the study of atmospheric pollution. It can be examined around a particular source on suitably chosen occasions, with recording instruments or at least with a large number of observers. It can be studied under extremely adverse weather conditions, with a 'crash' programme employing many observers, and the taking of samples for later examination. Or it can be treated as an item of climatology, with emphasis on long-period averages and statistical deviations from them. In Great Britain the climatological treatment remains the most popular, although the other two approaches have received increasing attention recently, especially since the London fog of December 1952. There are now about 1,500 sites where atmospheric pollution is continuously measured. An attractive booklet (Measurement of Air Pollution : Recommended Methods for Deposited Matter, Smoke and Sulphur Dioxide. Pp. iii +28. London : H.M. Stationery Office, 1957. 2s. net) produced by the Fuel Research Organization of the Department of Scientific and Industrial Research describes the apparatus used, all of which are extraordinarily simple. The deposit gauge and the lead peroxide apparatus for sulphur dioxide require no power or water supply, though they need the services of analysts. The smoke filter and volumetric sulphur dioxide apparatus demand simple laboratory facilities, and a few minutes 